The Geneva Papers on Risk and Insurance, 23 (No. 88, July 1998), 356-363

\title{
An Outlook on the Private Life Insurance Business in Japan
}

\author{
by Terumichi Tsuchida*
}

Given rapidly changing present circumstances, it seems to be rather difficult to predict the future. At the risk of predictive error, a view of emerging trends with a ten years horizon is discussed in this paper.

\section{Current Status of the Private Life Insurance Business}

For more than 40 years after World War, Japan enjoyed robust economic growth, and the private life insurance business in Japan posted the largest progress in the world. This had been mainly due to an increase of national income, the growing population, good public understandings to make use of life insurance, furthermore life insurance companies' successful management practices, and vigorous efforts of employees and sales forces. Current status of the private life insurance business in Japan is summarized as follows.

\subsection{Characteristics of the private life insurance business}

Life insurance products in Japan are provided by private life insurance companies, "Kanpo" or a postal life insurance administered by the Ministry of Posts and Telecommunications, and "Kyosai" or cooperatives. Premium income of private life insurance companies has been around $¥ 30$ trillion $^{1}$ in the recent years. The total amount of premium income including Kanpo and Kyosai comprised $41 \%^{2}$ of the world's premium income in $1995^{3}$, while the private life insurance companies' premium income represented $26 \%$ without Kanpo and Kyosai. These statistics indicate that Japan is one of the leading

* Chairman of the Board, Meiji Life Insurance Company, Tokyo.

$100=$ US $\$ 0.785$, US $\$ 1=127$, as of January 30, 1998 .

2 Sigma, No.4/1997, Swiss Reinsurance Company.

${ }^{3}$ A fiscal year of Japanese insurance companies is from April 1 to March 31, and respective fiscal years are used to aggregate data from each country. 
countries in the world's life insurance business. In the latter half of the 1980 s, the so-called "Bubble Economy" period, the premium income increased remarkably every year. However, in the 1990 s when the Bubble Economy burst, the premium income growth declined along with the stagnant economy, and minimal growth was witnessed especially in the last few years.

At the end of March, 1997, total assets of private life insurance companies aggregated 188 trillion, which represented $11 \%$ of the total private funds of financial institutions including governmental organizations in Japan, such that life insurance companies play a significant role as institutional investors. At the same time, the assets of Kanpo reached 100 trillion. Among the assets of the private life insurance companies, 58 trillion was invested in domestic loans whereas 44 trillion was allocated to domestic bonds, 31 trillion in domestic stocks, 9 trillion in real estates, 6 trillion in foreign loans, 13 trillion in foreign bonds, and 3 trillion in foreign stocks. Accordingly, the investment activities of life insurance companies are the center of attention in the stock, bond and foreign exchange markets.

Insurance in force amount of private life insurance companies amounted to 2,175 trillion, which is 47 million per household, or 17 million per person. Insurance in force amount of Kanpo reached 203 trillion and Agricultural Cooperatives life insurance with 245 trillion.

\subsection{Providers of the private life insurance business}

For more than a 20 year period after World War, The Japanese private life insurance industry was composed of 16 mutual companies and 4 stock companies. After the liberalization of the capital market in 1969, however, many foreign-capitalized insurance companies have started business, and in 1996 a number of life subsidiaries of non-life insurance companies were established. As of January 1998, there are 15 mutual companies, 26 stock companies, and 3 branches of foreign companies; for a total of 44 companies operating in Japan. Most of the larger companies are mutuals, whose aggregate premium income share was $89 \%$ in the fiscal 1996.

Out of 24 companies which newly entered into the life business after 1969, 13 were foreign-capitalized companies which were held by foreign companies by $50 \%$ or more and 11 were life subsidiaries of non-life companies. Out of the 13 foreign-capitalized companies, 4 companies have withdrawn from Japan by transferring their ownership to Japanese firms. The breakdown by country of 13 foreign-capitalized companies are 9 Americans, including 4 withdrawals, one Dutch, one French, one Swiss and one Swedish.

\subsection{Distribution channels and products}

One of the characteristics of distribution channels of the major life insurance companies in Japan is the dominating number of full-time female agents who exclusively work for one company. On the other hand, some middle size or smaller companies use independent agencies which engage insurance business as a sideline, in addition to female agents. Foreign-capitalized insurance companies utilize non-life insurance agencies and exclusive full-time male agents.

The core product of the larger companies has been whole life insurance with term rider. Some medium size or smaller companies and foreign-capitalized companies 
specialize in term insurance, individual medical insurance, particularly hospital insurance, or non-participating insurance. Variable life was introduced in the market in 1986, although, it has not been fully successful. Variable annuity and universal life have not been introduced in the market.

\subsection{Assumed interest rates and investment returns}

Currently, one of the critical challenges in management is the negative spread between assumed interest rates and actual investment returns. At the moment long-term interest rates are remarkably low. However, most of individual life insurance products being currently provided are assumed with $2.75 \%$ or $2.90 \%$ interest rates with group pension products at $2.5 \%$. Considering the existing policies sold until the period of the Bubble Economy, investment returns of greater than $3.5 \%$ is required. In order to mitigate negative interest spread, some companies utilize the profit margin from mortality and expense and others are using a part of the accumulated retained earnings in addition to above profit margins.

In the above situation, market interest rates are expected to resume to normal as soon as possible by settling bad loans of financial institutions, reviving economic growth, stabilizing the Asian economy and resolving other underlying issues. Meanwhile, private life insurance companies, along with the governmental authorities in insurance and finance, must take proactive measurement.

Furthermore, learning from the experience of extraordinarily low interest rates in the world modern economic history, the Japanese life insurance industry should prepare for the revision of individual insurance policy provisions which would allow the reduction of assumed interest rates when market yields of long term government bonds fall beyond certain spreads.

\section{Drastic Changes in the Business Environments}

As described in the previous sections, after the collapse of the Bubble Economy in Japan at end of the 1980's, Japanese economic growth has been almost flat in the 1990's. The private life insurance business in Japan seemed to have matured, yet continued to grow. However, the Japanese life insurance industry has taken a position to step forward to new developments in responding to the following drastic changes in business environments.

\subsection{Deregulation by new insurance business law}

The prior insurance business law, which was established as revised in 1939, needed to be substantially revised after 50 years to properly respond to today's business environment ${ }^{4}$. Thus a new insurance business law was enacted in 1995 and enforced in 1996. Some items in conjunction with this paper in the new law are described below.

\footnotetext{
${ }^{4}$ SeeTsuchida, Terumichi. "Insurance System Reform and The Future of the Life Insurance Business in Japan." The GENEVA PAPERS on Risk and Insurance, No.69, October 1993, by the Geneva Association. "Insurance System Reform and The Future of the Life Insurance Business in Japan." Mutuality, No.45, 1995, by AISAM.
} 
Under the old law, life insurance companies were not allowed to engage non-life business, and vice versa. The new law allows mutual entry between life and non-life business through their subsidiaries. Under the new law, six life insurance companies established non-life subsidiaries, while eleven non-life insurance companies started life subsidiaries, and they commenced cross selling of life and non-life products on October $1 \mathrm{st}, 1996$.

A principal distribution channel of non-life insurance companies operating in Japan has been independent agencies which can represent more than one insurance company. The majority number of these agencies engage in non-life business as a sideline to their core business. Newly established non-life subsidiary life insurance companies provide their products through their parent companies' distribution channel. As a result of new entry of non-life group into life business, the number of life agents under such agencies was drastically increased by 227,000 in only one year to 366,000 at the end of March 1997. At the same time, the number of exclusive life agents was 385,000 . In addition to these distribution channels, the new law introduced provisions enabling insurance brokerage and some insurance brokers already began their activities in Japan.

Under the old law, a mutual company had the responsibility of distributing the maximum possible portion of its surplus as dividends, to its members, i.e. policyholders of a mutual company. The new law puts more emphasis on appropriate retained surplus to maintain financial soundness of a mutual company as a going-concern.

In relation to the change on surplus distribution concept, the new law stipulates foundation fund raising, and a number of life insurance companies, principally major companies, raised foundation funds by over 800 billion. This improvement measures will certainly continue in upcoming years. For the purpose of enhancing solvency, subordinated loan has also become available to life insurance companies. In addition, new provisions of demutualization have been introduced.

\subsection{Insurance dispute between Japan and U.S.A.}

By introducing the new insurance business law in Japan, particularly the mutual entry between life and non-life business into each other's sector through subsidiaries, life companies' non-life subsidiaries have been allowed to offer personal accident insurance policies while non-life companies' life subsidiaries have been allowed to provide individual medical insurance policies. In the course of these changes, certain American companies, which had established respected positions in personal accident insurance and individual medical insurance markets, had reportedly expressed opposition against the deregulation. In responding to such movements, the U.S. government requested the Japanese government to liberalize non-life premium tables preceding the above deregulation.

According to the agreement between both governments established at the end of 1996, the liberalization of non-life premium tables will be implemented in July 1998 as a component of the "Tokyo Big Bang" described hereafter. The current regulation over personal accident insurance by non-life companies' life subsidiaries and individual medical insurance by life companies' non-life subsidiaries will be continued until the end of the year 2000 . 


\subsection{Acceleration of deregulation by "Tokyo Big Bang"}

The Japanese government recently advocated six major economic reforms. The financial system reform, or "Tokyo Big Bang", is to promote deregulation of various financial businesses, i.e. banking, securities, insurance, and encourage new entry into such financial business. Its principles are expressed as "Free", "Fair" and "Global." "Free" represents removal of regulation over free competition in the markets. "Fair" promotes transparency by improving disclosure. "Global" emphasizes harmony of regulations in international standards.

One of the highlights of the Tokyo Big Bang is the introduction of holding companies. In 1997, the Anti-Monopoly Law, which had previously prohibited a "pure" holding company whose operation is solely to hold stocks and control the management of other companies, was revised. Financial institutions can now diversify their business by deploying a holding company system. Under the current laws, however, a mutual holding company is not allowed, therefore, mutual insurance companies must utilize a downstream holding company system. Considering that the mutual holding company system has been legalized in certain jurisdictions in the U.S., there have been requests from the Japanese life insurance industry to legislate the mutual holding company system.

In the past, unit trusts or mutual funds as a saving vehicle have not been preferred by Japanese individuals. Under the new regulation introduced in 1997, insurance companies are permitted to allow unit trusts companies, including insurance companies' own affiliates, to conduct over-the-counter sales of unit trusts in insurance companies' branch offices. In addition, another revision of the Securities and Exchange Law is planned in 1998 to allow an insurance company itself to distribute unit trusts.

\subsection{Shift of business from public sector to private sector}

These days, in the stream of reform of government functions and deregulation, increasing opinions are heard that a government-controlled business, historically maintaining significant presence, should be privatized or abolished or their role should be limited in the areas where private companies can not serve consumers well. The size of "Yu-Cho," or postal savings managed by the Ministry of Posts and Telecommunications and Kanpo are perceived to be too large. Kanpo retains 100 trillion of total assets while $\mathrm{Yu}$-Cho has 224 trillion. There is emerging opinion that such government business unduly oppresses private business based on the special privileges enjoyed, ex. financial guarantee by the government, exemption of corporate income tax.

The aging of society in Japan has been progressing more rapidly than any other developed country in the world. While the current rate of elderly people in Japan ages 65 or older is almost the same as that of the U.K., France, and Germany, it is predicted that the rate will be higher than those countries in the next 20 years. The public pension fund in Japan is basically financed by the "pay-as-you-go" method. To support a rapidly aging society, it is impossible to maintain the national pension system without raising premiums or commencement age of benefit payment. The Japanese government is preparing a thorough reform of the pension system in 1999 and the project is under consideration including a change to "funding" method. 
The financial condition of the national health insurance system is distressed due to the increasing medical costs along with the aging of society. Whereas the Japanese government reduced the benefit level of national health insurance in 1997, this revision was not sufficient to resolve a deficit in the health insurance system. The government has a plan to improve the efficiency of the health insurance system much more drastically. In addition, needs for nursing care will be increasing. New legislation enacted in 1997 introduced the public nursing care insurance system which is to become effective in the year 2000 .

\section{The Developing Private Life Insurance Industry}

The future Japanese economy will be steadily growing with the background of Japan maintaining the world's largest creditor power, a high level of national savings, and qualified manufacturing technology. This growth is under way by resolving bad loans, normalizing the historically lowest interest rates, progress toward deregulation, expansion of private business in the fields of pension as well as health and welfare, and stable growth of the Asian Economy after the settlement of the Bubble-Burst Economy. The private life insurance industry will continue to grow with new developments by coping with the confronting challenges, even though its growth rate will be lower than that of the past rapid-growth period.

\subsection{Spread of life insurance and change on consumers' attitudes of purchasing life insurance policies}

In Japan, life insurance is widely spread, as $81 \%$ of males and $75 \%$ of females have a policy with either private life insurance companies, Kanpo, or Kyosai while $93 \%$ of households do. The amount of financial assets Japanese individuals have is approximately 1,200 trillion, out of which the private life insurance industry shares a remarkable $14 \%$.

In the past several years, the Japanese economy as well as individual income has been sluggish. Also with the deregulation of financial fields under way, consumers, who have acquired advanced financial knowledge, have a tendency of purchasing financial products by closely comparing each product. They have become more attentive when buying life insurance policies that satisfy their life planning needs.

\subsection{The Diversification of distribution channels}

In order to respond to consumers' needs of highly sophisticated life planning, much more important than ever will be consulting services offered by financial planners with professional knowledge in such areas as analyzing appropriate coverage for consumers, explaining profile of life insurance products, comparing financial products of other sectors, i.e. banks, security firms, and taxes. At the same time, the roles of sophisticated life agents will continue to be essential.

In the case of small size term insurance and simpler products, however, some consumers are expected to prefer lower priced products even without consulting services by agents. It will be more important to diversify distribution channels by types of products and premium ranges. Increased use of brokers and independent agencies, and expansion of over-the-counter sales, direct marketing and other new channels are foreseen. In the 
progress of mutual entry between life and non-life business through subsidiaries, packaged products of life and non-life insurance will be increased.

\subsection{An aging aociety and the expansion of private business}

The individual benefit amount of national pension is predicted to be lowered to the minimum life-supporting level and more emphasis will be put on the funding method, as a result of the revision of the national pension system currently under consideration. Under the circumstances, life insurance companies, which are prominent as carriers of long-term savings and have capable actuaries, and their investment advisory subsidiaries, are expected to play an enhanced role in expanding private pension business.

As the coverage of national health insurance is assumed to be reduced, the private life insurance industry is expected to be active in the field of medical insurance. In addition, together with the introduction of the governmental nursing care insurance, demands for wellness promotion programs, including nursing care related services, offered by private life insurance companies would be heightened.

With an aging society and the decreased role of public sectors, the need for protection against survival, sickness, disability, nursing care and so forth is increasing in addition to death protection. With regard to product developments, whole life with a term life rider currently being a mainstream, innovative product ideas including pension, medical insurance and nursing care related services will be more important than ever.

\subsection{Developments into overseas markets}

The Japanese market is open to foreign insurance companies. In fact, thirteen foreign insurance companies have already established business in Japan, and one successful company maintains total assets of over 2 trillion.

While the number of domestic and foreign life insurance companies in Japan is expected to increase, the Japanese population will follow a trend of decrease. It is inevitable that the life insurance market in Japan will become more matured and competition will certainly be intense. Facing these challenges, private life insurance companies are expected to be superior to other financial institutions such as Kanpo, Kyosai, commercial banks, trust banks, and security houses in product developments, improvement of operational efficiencies, and upgrading customer service.

Consequently, developments into overseas markets, particularly the Asian markets which are anticipated to grow in the long run, will be a mid-term subject. Some companies have been increasing their presence in several Asian countries. Placing the first priority on strengthening the domestic operations in the short run in order to overcome the financial Big Bang, major life insurance companies will be pursuing developments in Asia and other parts of the world in the upcoming decade.

\section{Postscript}

1. This paper was written in January, 1998 to fulfill the responsibility of Director of the Geneva Association. 
2. The author had served as Chairman of Meiji Life until the end of March, 1998 and thereafter has been the Senior Advisor of Meiji Life.

3. The author expresses gratitude for assistance by Messrs. Nobuyuki Kamohara and Motohiko Sato of International Department, Meiji Life, and Douglas Goto, Executive Vice President, Pacific Guardian Life. 